\title{
Sustainable Alternative Wetland Management Strategy for Kalu Oya and Mudun Ela Basins of Sri Lanka
}

\author{
Nishan P. Sakalasooriya \\ Department of Geography, University of Kelaniya, Kelaniya, Sri Lanka \\ Email:nishan@kln.ac.lk, sakalasooriyanp@yahoo.com
}

How to cite this paper: Sakalasooriya, N. P. (2021). Sustainable Alternative Wetland Management Strategy for Kalu Oya and Mudun Ela Basins of Sri Lanka. Open Journal of Social Sciences, 9, 543-563. https://doi.org/10.4236/jss.2021.92035

Received: January 25, 2021

Accepted: February 23, 2021

Published: February 26, 2021

Copyright $\odot 2021$ by author(s) and Scientific Research Publishing Inc. This work is licensed under the Creative Commons Attribution International License (CC BY 4.0).

http://creativecommons.org/licenses/by/4.0/ (c) (i) Open Access

\begin{abstract}
As a tropical island, Sri Lanka has highly diversified wetlands. Even though, the wetlands in the Western Province of Sri Lanka are highly rich in biodiversity, they are endangered due to the human development processes. Consequently, the sustainability of the wetlands and the economic and social life of the settlers who settle near and in the wetlands are significantly destructed. Due to the population growth and the rapid infrastructure development, the wetlands have been shrunken. Many land hungers have been emerged during the process of the city development and Megapolis. In this dichotomy, creating a policy framework on the wetlands is vital. There are two major objectives of the study, first, to describe the current impacts of socio-economic activities to the wetlands; second, to propose sustainable alternatives for preparation of the wetland management strategy for Kalu Oya and Mudun Ela Basins which are in the southwestern part of Gampaha District in Sri Lanka. The used strategies of the survey are fivefold: case studies of each sub catchment, measuring land use changes using secondary data and verified by the field visits, questionnaire survey for primary quantitative data, field observations, and focused group discussions for qualitative data. Even though, they are the two basins of the Kelani River which is $145 \mathrm{~km}$ long being the fourth longest river in Sri Lanka which are also highly fragile sub catchments of the main catchments of the River. More than 80 percent of the neighboring settlers and settlers of wetlands do not know the significance and uniqueness of the wetlands and their life support services to the human beings and the other ecological services of these wetland ecosystems. Economic activities of all the wetlands are approximately equal and the usage of wetlands has been transforming from agricultural to industries and small services.
\end{abstract}




\section{Keywords}

Wetlands, Sustainability, Sri Lanka, Kelani River

\section{Introduction}

During the past 25 years though the Sri Lankan Authorities have increasingly recognized the importance of wetlands and their management, still the wetlands of Sri Lanka are highly endangered by unauthorized and unsustainable human activities. Some of the studies have clearly pointed out that the wetlands of Sri Lanka, especially those in the western province have been converted from wetlands to wastelands, as a result of human induced activities and development initiatives. Consequences of these activities have led the wetlands to be used as dump sites for garbage and urban waste (IUCN, Sri Lanka and the Central Environmental Authority, 2006; Kotagama \& Bambaradeniya, 2005). In Sri Lanka, the conservation of wetlands has been vested mostly with the wildlife sector as reflected by the Fauna and Flora Protection Ordinance of 1938 and its amendments. All the successive governments of Sri Lanka have paid their attention to protect the wetlands of Sri Lanka and these interests have resulted in the Convention on Wetlands, referred to as the Ramsar Convention which is an intergovernmental framework for wetland conservation which is adopted in 1971 (Daily News, 2019).

South-West part of Sri Lanka consists precious wetlands expanses, which are highly exposed to human activities as a result of being closer to the economic hub of (City of Colombo) the country. Hence the demand for the lands in the area near to the city of Colombo is very high. Most of the time it is visible that the precious wetlands are also being utilized for various purposes. Wetlands play a vital role in human survival and they are considered as the world's most productive ecosystems. They are also known as cradles of biological diversity that accommodate water and productivity upon which innumerable species of plants and animals depend for survival. Considering all these matters, this survey has been carried out to identify the socio-economic background of the people who are living in the wetland areas in the Kalu Oya (KO) and Mudun Ela (ME) basins $\left(7^{\circ} 7^{\prime} 60^{\prime \prime} \mathrm{N}\right.$ and $\left.79^{\circ} 54^{\prime} 0 " \mathrm{E}, 78 \mathrm{~km}^{2}\right)$ of the Kelani River which is $145 \mathrm{~km}$ long being the fourth longest river in Sri Lanka (Lekamge, Dayananda, \& Weerasinghe, 2018).

The basins, located in the southwestern part of the Gampaha District in Sri Lanka, have been divided into 18 subcatchments by the Sri Lanka Land Reclamation and Development Corporation (SLLRDC), and these subcatchments lie over the 05 DSDs with high population density named Wattala, Mahara, Kelaniya, Biygama and Ja-Ela. There are 135 Grama Niladhari Divisions in 06 DSDs. The total population of the DSDs is 501,988 and there are 134,404 housing units. Figure 1 shows the sub-catchments of catchment areas (Census of Population 
and Housing Sri Lanka, 2012). Wetlands in these two basins can be identified as highly sensitive and highly fragile wetlands which are located in the suburban region in the Western Province of Sri Lanka. The Kalu Oya basin is a relatively small catchment which is located between the Ja Ela basin in the North and Kelani river basin to the South. Kalu Oya extends to $58 \mathrm{~km}^{2}$. Total catchment area of the Mudun Ela basin is about $12 \mathrm{~km}^{2}$. The elevation of these catchment areas varies from $1.0 \mathrm{~m}-20.0 \mathrm{~m}$ MSL. These basins belong to the Wet Climatic Zone which receives more than $2500 \mathrm{~mm}$ rainfall annually. The mean temperature is about $27.90 \mathrm{C}$. These two basins have been divided into 18 sub catchments which are located in 05 DSDs with high population density named Wattala, Mahara, Kelaniya, Biygama and Ja-ela (Figure 2). There are 135 Grama Niladhari Divisions (GND) in 06 DSDs. The total population of the DSDs is 501,988 with 134,404 housing units (Census of Population and Housing Sri Lanka, 2012).

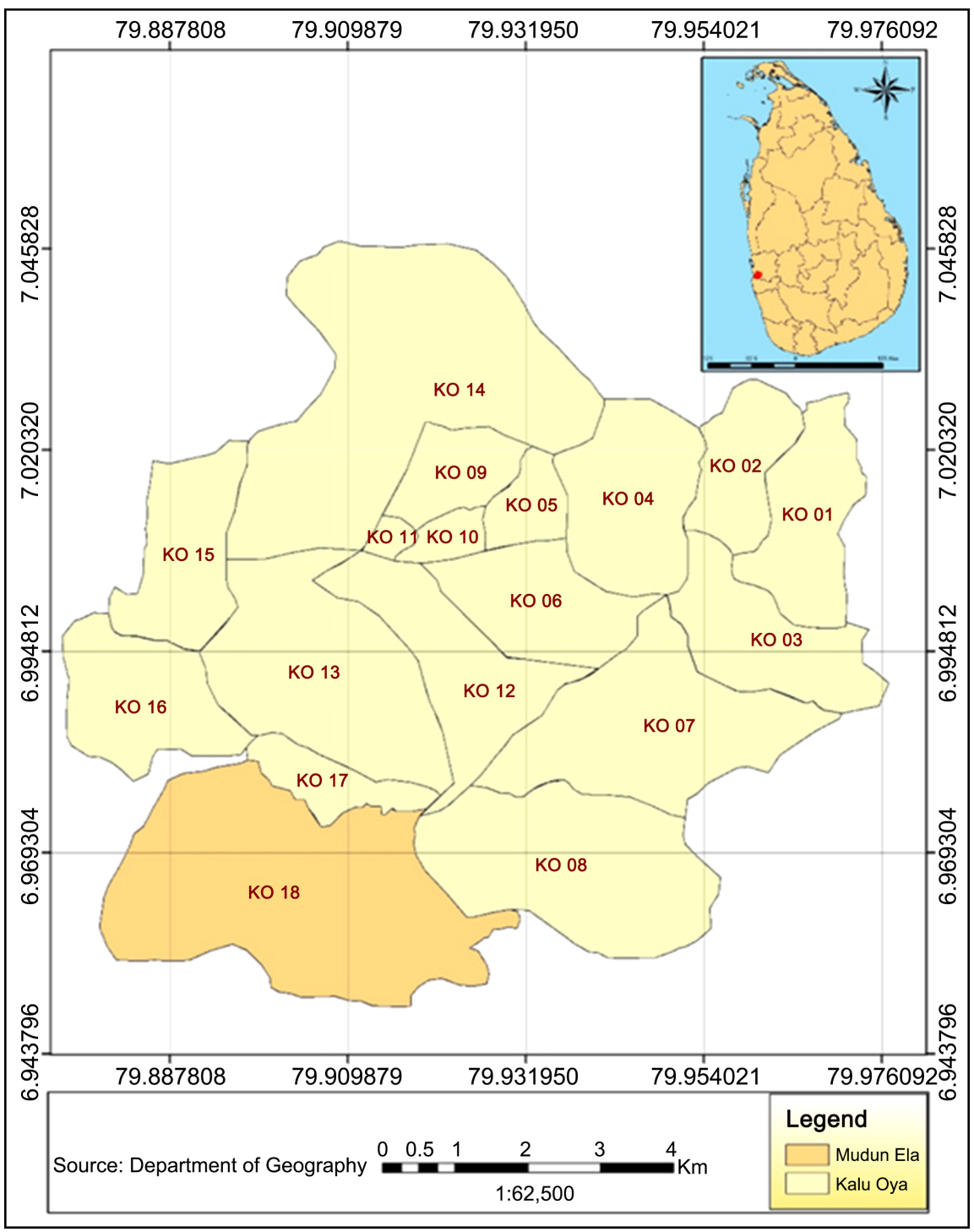

Figure 1. The relative location of the Kalu Oya and Mudun Ela. 


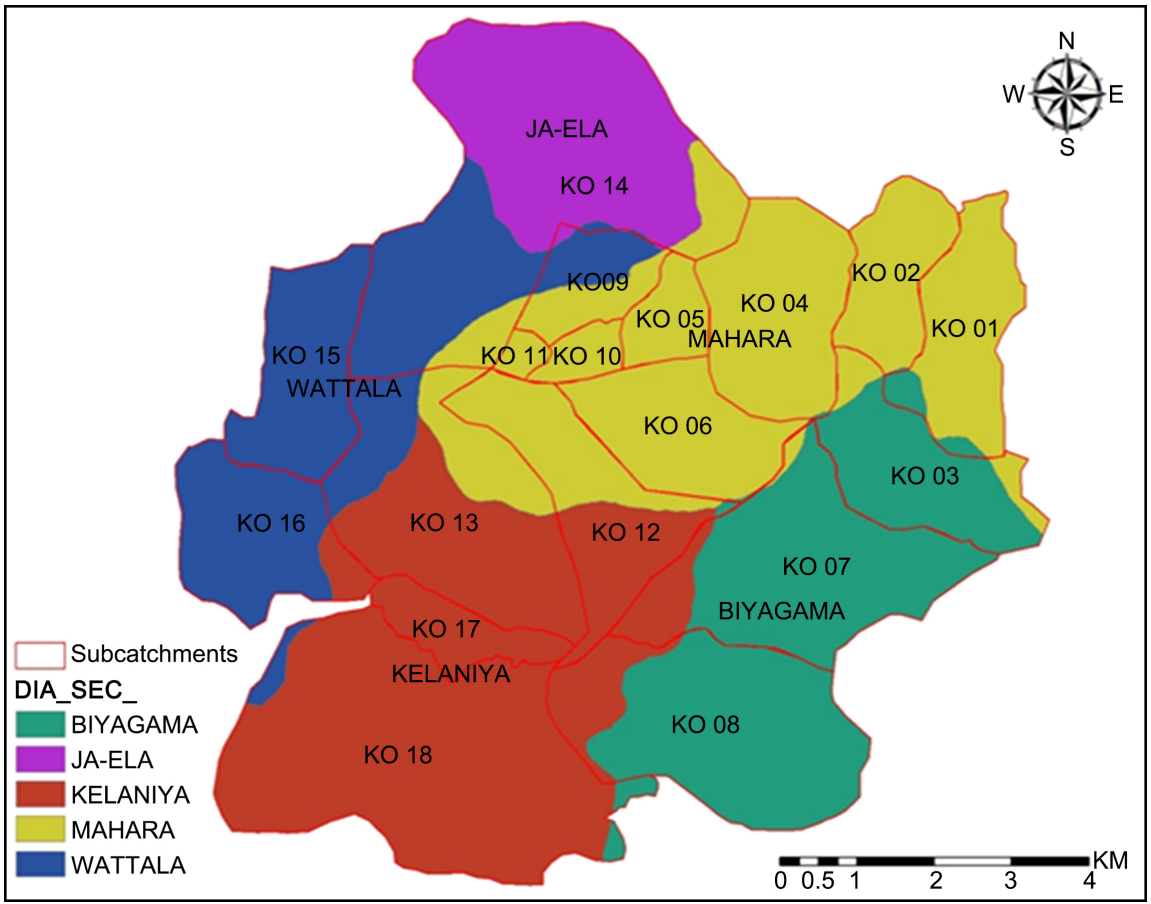

Figure 2. Divisional secretariat divisions in Kalu Oya and Mudun Ela Basin.

\section{Methodology}

This survey mainly investigates the Socio-Economic characters, key pressures and threats, institutional arrangements, policy setting, and archaeological sites in each wetland area. Hence both secondary and primary data were collected to fulfill the aims by applying mixed methods. Mixed method research is an approach to inquiry that combines or associates both qualitative and quantitative methods. It involves philosophical assumptions, the use of qualitative and quantitative approaches and the mixing of both approaches in a study. Thus, it is not only sample collecting and analyzing both kinds of data but also involves in the use of both approaches in random, so that the overall strength of a study is greater than either qualitative or quantitative research.

Semi-structured questionnaires (SSQs), Focused Groups Discussions (FGDs), Key Informant Interviews (KIIs), Case Studies (CSs) and Field Observations (FOs) are the main data collecting techniques. On the other hand, the Global Positioning System (GPS) and 1:50,000 topo sheets published by Survey Department in 1989 and Google image 2015 were also used. According to the main objectives, data collection and analysis are summarized as follows.

To achieve the above-mentioned objectives, secondary and primary data have been collected. The necessary qualitative and quantitative data is gathered by SSQs, FOs, FGDs, and CSs. To get the idea about these tasks of the survey objectives, the research has used 850 SSQs. Fifty Households Heads (HHs) or their close relatives have been selected for the sample out of the population in the 300 $m$ buffer zone in each sub catchment. The questionnaires have been given to the randomly selected HHs or their close relatives. When it comes to identifying the 
socio-economic characteristics of the sub catchment, it has been done through frequency run and cross tabulation using SPSS package and Excel. The results have been mainly shown using tables and graphs.

A multistage purposive sampling procedure was applied for the selection of the 850 household heads and their close relatives. Applying GIS technology, this sampled population was selected within 300-meter buffer zone from the periphery of the wetland and sampled population represents all 18 sub catchments in the basins. Justifying the sample, 09 locations were selected on the right banks of the wetland and the others on left bank (see Figure 3). Approximately 50 respondents were selected from each sub catchments.

The relevant information regarding the site descriptions, institutional arrangements, land ownership, and policy setting of the Sri Lanka Land Reclamation and Development Corporation (SLLRDC), Urban Development Authority (UDA), Central Environmental Authority (CEA), Department for Wildlife Conservation (DWLC), Agrarian Development Department (ADD), and Road Development Authority (RDA), have been personally visited, interviewed and obtained from the authorized officials and confirmed their activities which are being implemented and to be implemented in each wetland areas in terms of written documents.

To prepare the inventories, the research has used institutional secondary data. When it was preparing the inventory for Socio Economic characteristics of the wetland areas, the information available at the Divisional Secretariat Divisions were used. The other task was to complete the Institutional current projects and future projects which have already been planned. To achieve this task, the data from CEA, RDA, etc. were used. Some of the other secondary data and primary data sources are shown in Table 1.

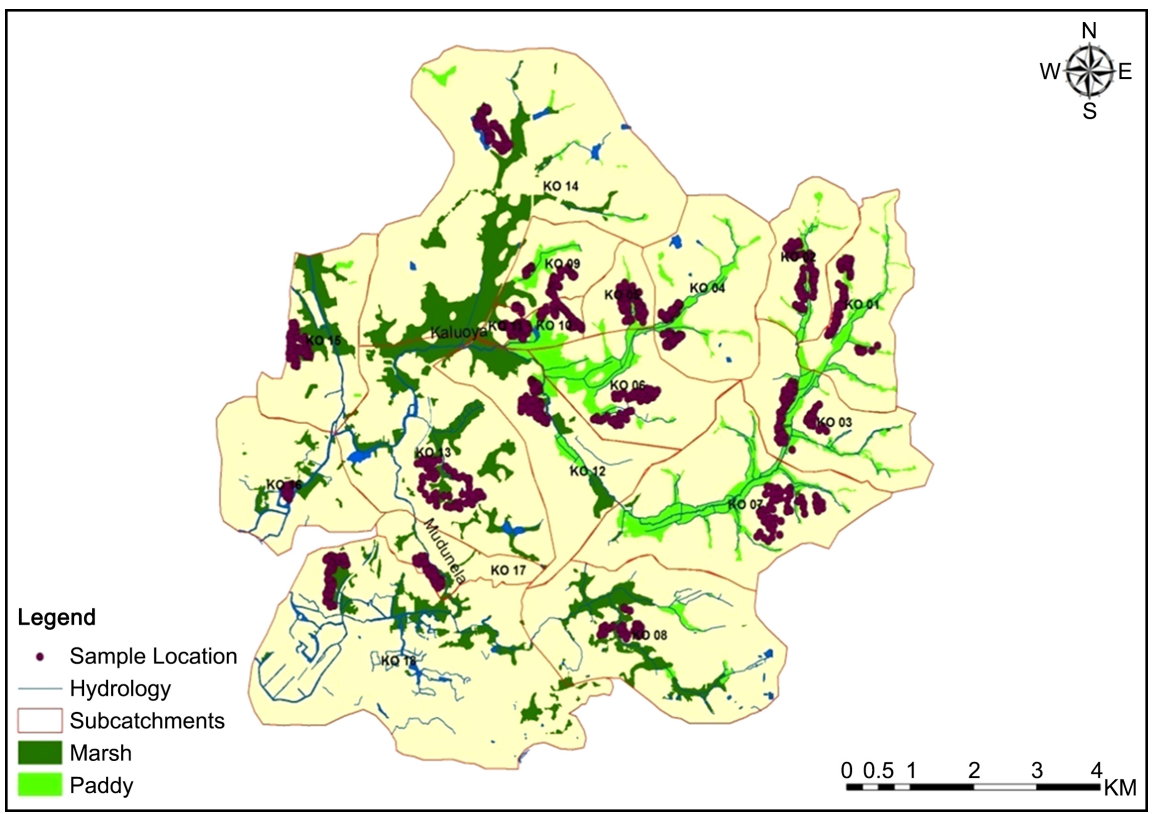

Figure 3. Study sites of the survey. 
Table 1. Data collection sources.

\begin{tabular}{cc}
\hline Collection methods & Data Sources \\
\hline SSQs & From the selected sub catchment area \\
KIIs & \\
Geographic Information Systems (GIS) Shape & Surveying Department \\
files, Topographic sheets and Google Earth 2015 & Google Earth \\
Desk Review & SLLRDC, CEA, UDA, DWLC ADD, RDA. \\
KIIs & DSDs, LAs belongs to the KO and \\
Sampath Pathikada & ME basin areas \\
Resource Profile &
\end{tabular}

\section{Results of the Study}

\subsection{Basic Information of Families}

According to the study, $83.6 \%$ of the sample represents are the male respondents as they are the majority among the household heads. There are not any respondents younger than 21 years old. According to the figures, $51.4 \%$ of the sample represents the senior settlers (51 years or above) of the settlements which are located closer to the wetlands. $95.1 \%$ of the sample is married and $1.45 \%$ is widowed. The religious composition of the study sites is varied, and Buddhist are the majority (65.4\%) and Catholic, Hindu, and Islam represents $26.7 \%, 3.7 \%$, and $1.2 \%$ respectively. The percentage of $\mathrm{O} / \mathrm{L}$ passed or with higher educational qualifications is $70.5 \%$. There are $3.2 \%$ of graduates and $0.5 \%$ of postgraduates among household heads. Majority of the settlers on the wetlands or nearby areas work in private sector $(25.3 \%)$ and $24.4 \%$ are self-employees. $13.5 \%$ of persons do not have a considerable livelihood and they are dependents. Figure 4, Figure 5 and Table 2 show more relevant data of the sample and total population in the study areas.

Figure 4 illustrates the distribution of sample population by catchments of both Kalu Oya and Mudun Ela basins and Figure 5 shows the occupation patterns. Our target was to select 50 household heads from each catchment, but it was limited due different kinds of unavoidable circumstances like security of the enumerators, cultural issues of the settlements, and the natural environment of the area. Therefore, the total number of selected respondents is 850 and among them are the household heads or their close relatives. The survey has been planned to collect data to discover the existing socio-economic situation of the settlers of the catchment areas of Kalu Oya and Mudun Ela basins.

\subsection{Land and Land Fragmentation}

Generally, there are small landowners in the catchments. The data shows that there are $6.0 \%$ of total settlement lands which exceeds 50 perches or more. $25 \%$ percent of the lands are less than 25 perches. The lands of the size between 7 perches to 12 perches accumulated $37.6 \%$ of the total lands. All these lands have 


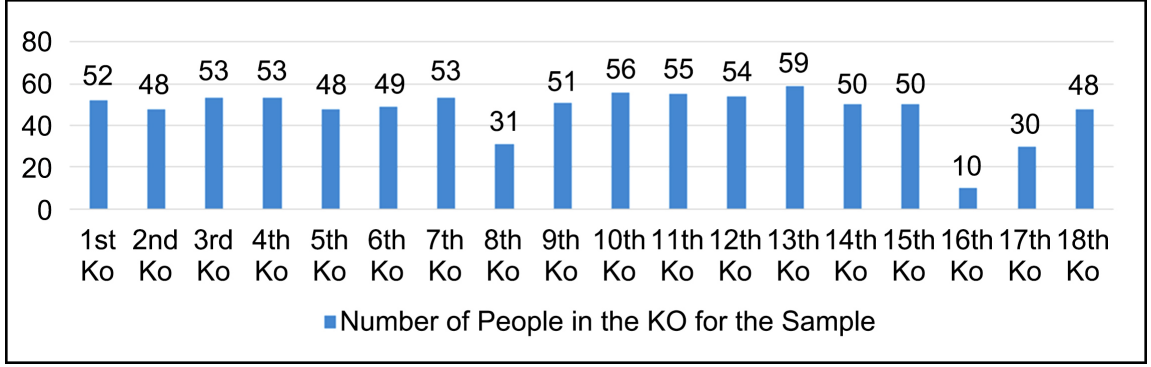

Figure 4. Sample representation of catchments. Source: Field Survey March/April 2019.

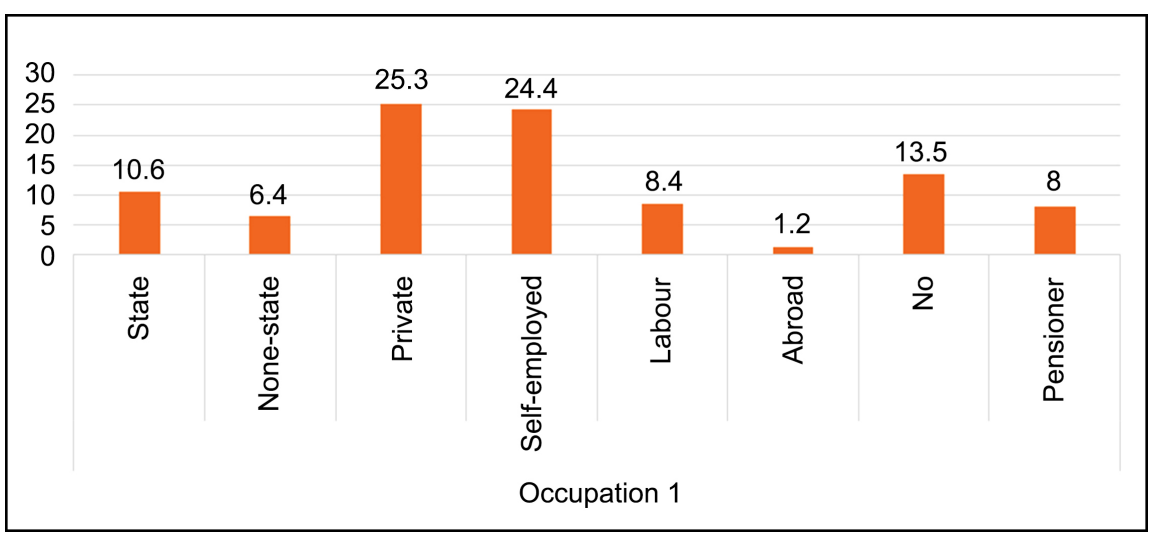

Figure 5. Occupation. Source: Field Survey March/April 2019.

Table 2. Ethnic composition of population.

\begin{tabular}{cccccc}
\hline & Sinhala & Tamil & Muslim & Malay & Barger \\
\hline House holder & 782 & 42 & 5 & 6 & 1 \\
percentage & 92 & 4.9 & 0.6 & 0.7 & 0.1 \\
\hline
\end{tabular}

Source: Field Survey March/April 2019.

mainly been utilized for housing purposes. Most probably the physical nature of lands in the wetlands is similar to its appearance. The study has attempted to identify these lands under four major categories, High wetlands, filled lands, non-filled lands, and cultivated lands. The first three categories were easily identified by depending on the nature of the soil. Cultivated lands were identified by the field observations and the information of the respondents. According to the data analysis, cultivated lands are very limited and the percentage of all the cultivated lands is 0.47 . Wetlands which are very foggy and muddy represent 18.3 percent of total land area. $21.6 \%$ of lands of the catchments have already been filled. Non-filled lands are the major category of lands with $58.7 \%$ of the total lands. The nature of the lands of the settlements is varied by catchments as the data shows that $80 \%$ of the total land area of the catchment $18 \mathrm{KO}$ belongs to high wet boggy lands while there are no any high wet boggy lands in the catchment KO 11. All the settlements of the catchment have filled lands in different levels of percentages. In general, there are no considerable percentage of culti- 
vated lands of the settlements except in KO 08, 10, 13. Figure 6 express the evidence for land fragmentations and compact settlement pattern in the sampled catchment 01 .

\subsection{Land Use Pattern of the Basins}

Kalu Oya and Mudun Ela, these two catchments are situated in more precious, economically active, and highly populated expanse of the western part of the country. As the area is very close to the commercial capital; Colombo, the land value and the usage are very much higher than other parts of the country. The study area consists popular cities like Wattala, Ja-Ela, Biyagama, Mahara and Kelaniya. Hence a high population density can be seen with advanced services in this expanse. This creates the major portion of land use pattern belongs to the home gardens. Total area which belongs to the mentioned Kalu Oya \& Mudun Ela is $78.856 \mathrm{~km}^{2}$ (7885.6 hectares). Table 3 shows the existing land use patterns in the study area. Paddy lands cover $4.95 \mathrm{~km}^{2}$ or 495 hectares and the marshy lands (6004 Hectares) of the wetland are situated in the upper middle part of the study area. It is clearly visible that the home gardens have been conquering the area in a very successive way. Marshy lands and paddy fields come in the second and third status in the land use pattern in this area Paddy lands and the marshy lands of the wetland are situated in the upper middle part of the study area. It is clearly visible that the home gardens have been conquering the area in a very successive way. Marshy lands and paddy fields come to the second and third status in land use pattern in this area (see Figure 7).

\subsection{Flood Prone Lands of the Catchments}

The percentage of annual flood risk lands is 48.4. The settlers of these lands have been adopted to live with flood as it is a common risk during the south-west monsoonal period from May to August. All the lands of the settlements on Catchment 16 have annually faced flood. It has $80 \%$ high wetlands with $20 \%$ filled lands. On the other hand, catchment $\mathrm{KO} 05$ is totally free from the flood risk, therefore, $89.6 \%$ are non-filled lands. On the other hand, soil erosion is very high in the surrounding areas and the moderate erosion could be reduced using the suitable agronomic practices. Appropriate conservation measures must be implemented for the areas under high, very high and extremely high vulnerability to soil erosions within the Kalu Oya and Mudun Ela basins to reduce the sediment transport (Lekamge, Dayananda, \& Weerasinghe, 2018).

Three types of housing units have been identified by this study, permanent, semi-permanent, and shanty (see Figure 8 and Figure 9). According to the survey data, $91.4 \%$ of total housing units are permanent and only $3.2 \%$ are shanties. These data show that the residents of the wetland areas are adopted to live in a wetland, and they have chosen the wetlands as their permanent residents. In catchment $\mathrm{KO} 02,03$, and $07,100 \%$ of housing units are permanent. The catch- 
ment KO 15 has $30 \%$ of temporary huts because of high flood risk and boggy soil condition of the catchment. Majority of the settlers who lived in the temporary and semi-permanent housing units are lower income families and they are economically and socially backward. There are $96.2 \%$ of total housing units made up of walls of soil bricks or concreate bricks.

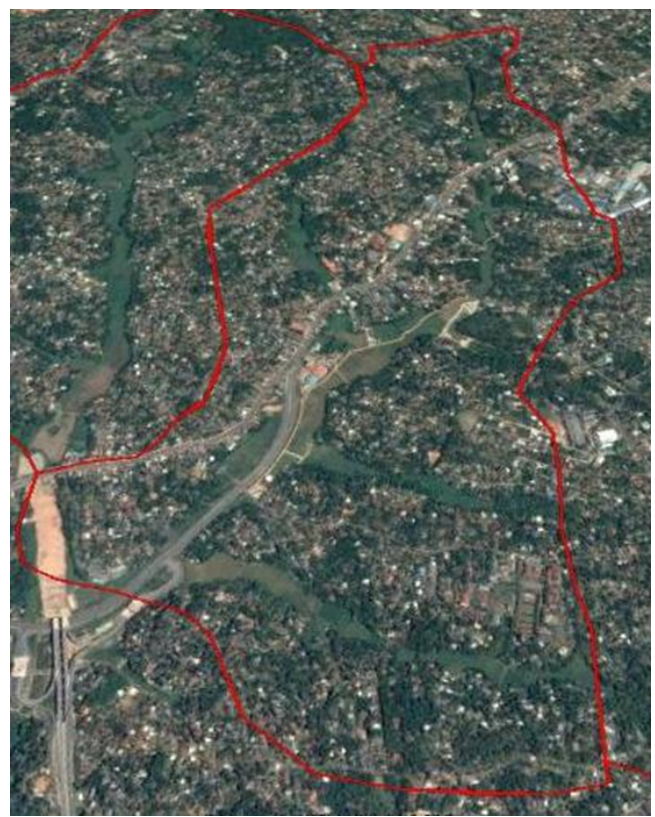

Figure 6. Current settlement pattern of the catchment 01 (Google Earth Images (2014-20020)).

Table 3. Existing land use of Kalu Oya and Mudun Ela.

\begin{tabular}{cc}
\hline Land use type & Extent $(\mathrm{sq} \cdot \mathrm{km})$ \\
\hline Home Garden & 60.04 \\
Paddy & 4.95 \\
Barren Land & 2.43 \\
Rubber & 0.48 \\
Playground & 0.30 \\
Unclassified & 0.13 \\
Scrub & 2.57 \\
Marsh & 6.99 \\
Hydro & 0.73 \\
Waste & 0.11 \\
Rock & 0.01 \\
Park & 0.01 \\
Other & 0.11 \\
Total & 78.86 \\
Data Source: Land use map, 1989, DoS & \\
\hline
\end{tabular}




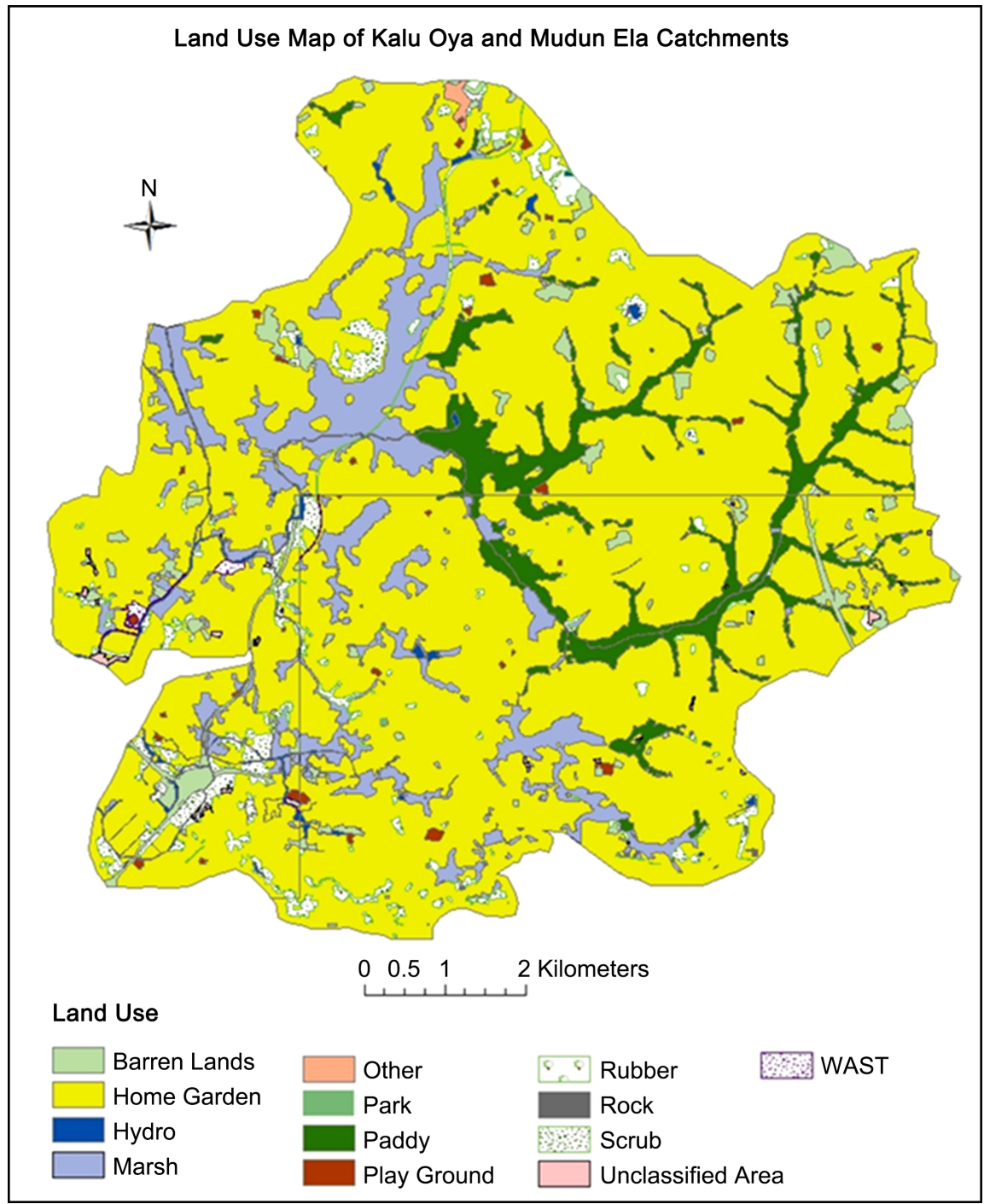

Figure 7. Land use map of Kalu Oya and Mudun Ela catchments. Data Source: Land use map, 1989, Surveying Department of Sri Lanka.

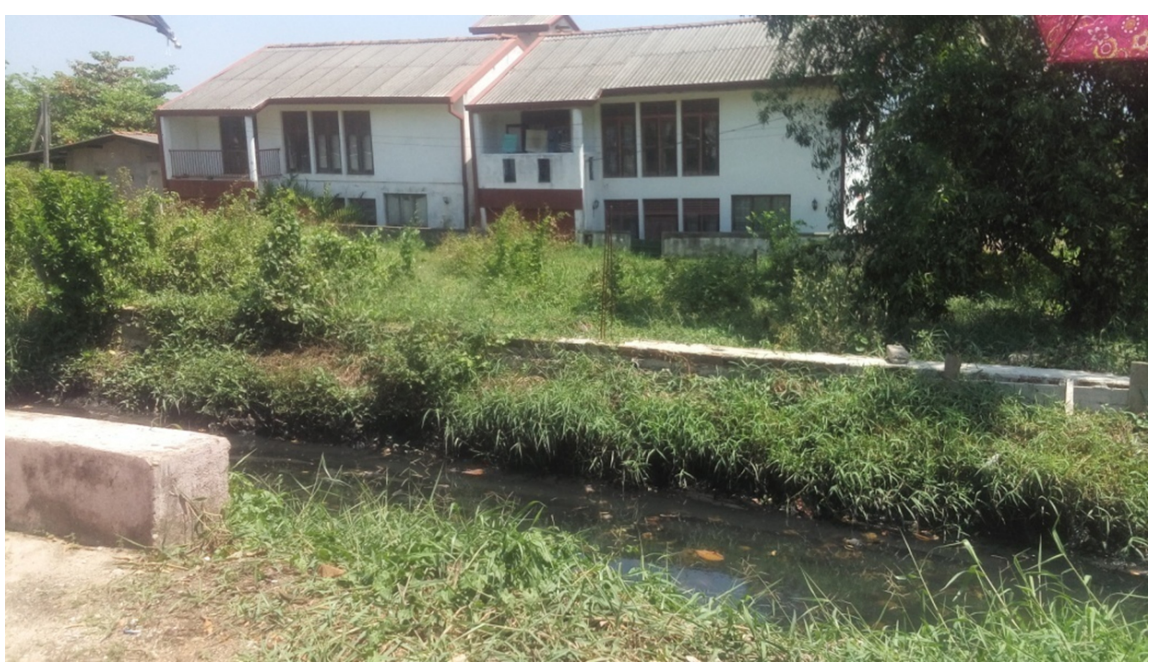

Figure 8. Permanent houses in Catchment KO 16. 


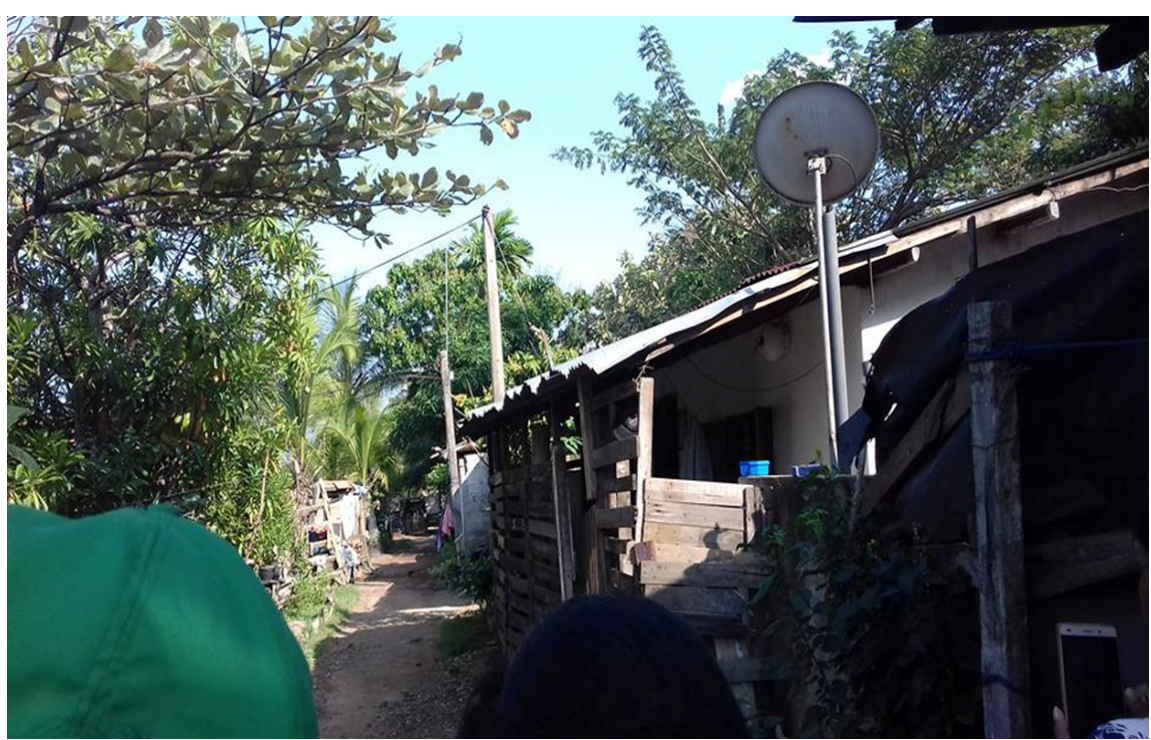

Figure 9. Semi-permanent and temporary housing units on the right bank of the Kalu Ela.

\subsubsection{Types of Drinking Water Sources}

Main water supply lines, and their owned wells. More than half of the population, $57.6 \%$, have been enjoying pipe borne water from the main water supply line by the government. As mentioned above, majority of the housing units are permeant and they have rights to enjoy the pipe borne water from main water lines. Others (42\%) obtain water from their own wells. Water availability of these wells are very high because of the nearby wetlands. Only problem is that during the rainy season the well water cannot be used because of flood. According to the case studies and observations, the consumers of well water are reducing because of the low water quality. $32 \%$ of the well water consumers do not use this water for drinking purposes. They are also willing to use pipe born water. Three decades ago, all the wetlands had high quality water. One fifth of the population use wetland as their main water source and they have built their wells on the wetlands. There are some natural water ponds and manmade tanks which are used for animal related purposes and other agricultural purposes (see Figure 10 \& Figure 11).

The study of water quality in rainy season of $\mathrm{KO}$ and $\mathrm{ME}$ shows that the Nitrate levels were below the standard, and the wetlands which are situated at the fish market outlet exceeded the standard levels of conductivity, TDS, salinity, phosphate, COD and BOD5 levels. oil and grease levels in all the areas of wetland were extremely higher than the standard limits. This may be due to the service stations located at the upper catchment of the area and these service stations might be discharging oil and grease contaminated water to the surface runoff (Thotagamuwa \& Weerasinghe, 2019). On the other hand, the soil systems of the wetlands are highly contaminated with agrochemicals and the water is also contaminated (Piyadasa, Herath, Uthpalani, \& Sameera, 2018). 


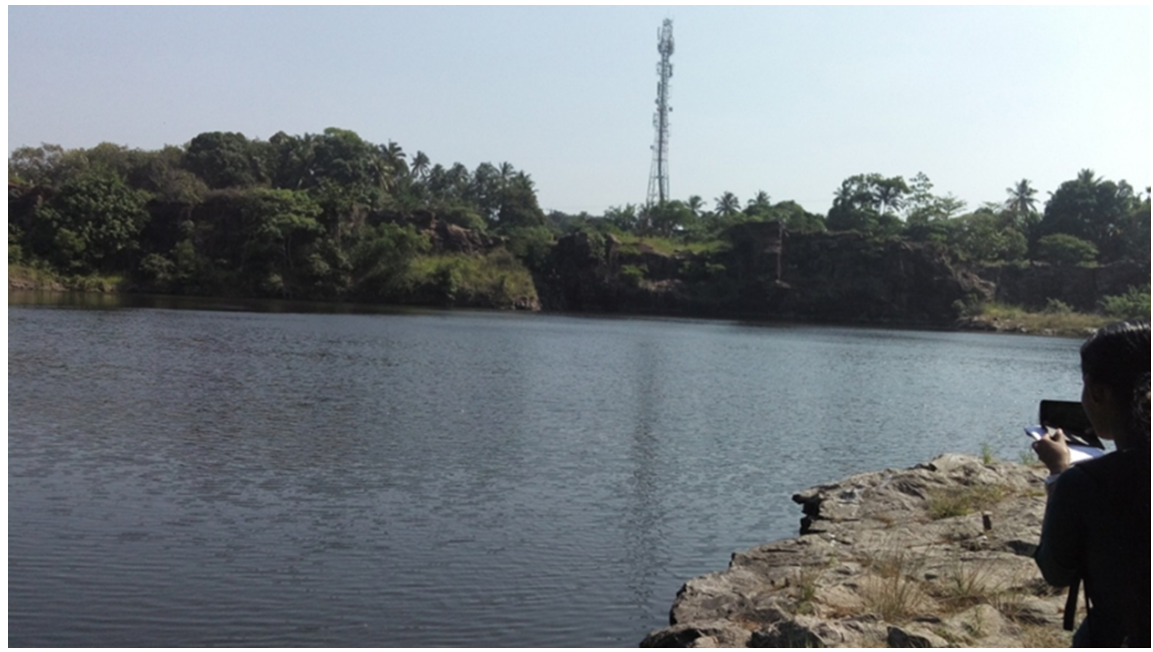

Figure 10. The Water tank of the rock quarry, Neligama in Catchment KO 04.

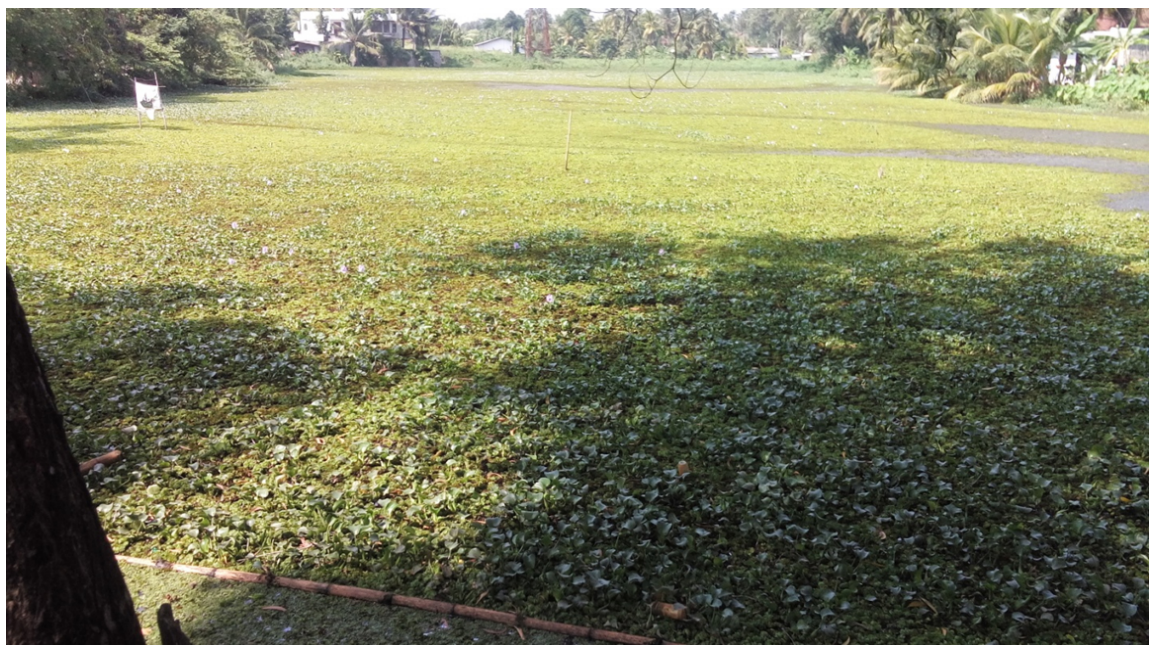

Figure 11. Peralanda Tank filled by invasive plants, Ragama, Catchment KO 14.

\subsubsection{Sanitation}

All the settlers have good sanitation facilities and $99.9 \%$ have their own private water sealed toilets in their houses or outside the house but within the land. There are no significant differences among the catchment areas, and it verifies the relationship between settlers and the wetlands. These data have clearly shown that the dependency level is very low, and the percentage is 1.7. It means that there is no considerable relationship of their livelihood with the wetlands. They use these wetlands as dormitories. As mentioned in Figure 12, 88.2\% of settlers have a good understanding about location of their houses and they are aware that their houses are located within or near a wetland.

\subsection{Types of Drinking Water Sources}

This analysis is depended on the views of respondents. Advantages of wetlands to settlers of the settlements can be identified under different categories, $36 \%$ of total families do not have any type of advantages from the wetlands. It means, 
they do not have positive relationship with the wetlands. $19.4 \%$ of the families dispose their wastewater to the wetland directly, and $9.4 \%$ of the families harvests tender green leaves from wetlands for their foods. Animal grazing is a common scene on wetlands and $2.9 \%$ of these two major catchment areas benefit to feed animals like goats, cows, bulls, chicken, pigs, and ducks. These farms or herding on the wetland are disturbing for the natural successions of the vegetation and supports to increase the population of mosquitos as well. Farms of pigs are directly polluting the water sources and the quality of air with stinky odors.

The study reveals that $11.3 \%$ directly dispose their liquid waste to the wetlands and another $84.5 \%$ indirectly send their wastewater to the wetlands (see Figure 13). There are $4.2 \%$ who dispose wastewater to the septic tanks of MC and common sewage system. In our observations, mostly the settlers dispose their waste to wetlands, and this is one of the major factors that have been affected the pollution of the wetlands. On the other hand, the wastewater drainage systems of the surrounding areas flow to the wetlands. As said by the settlers, water which is obtained from wells located in wetlands are not suitable for drinking because of stink and bad taste.

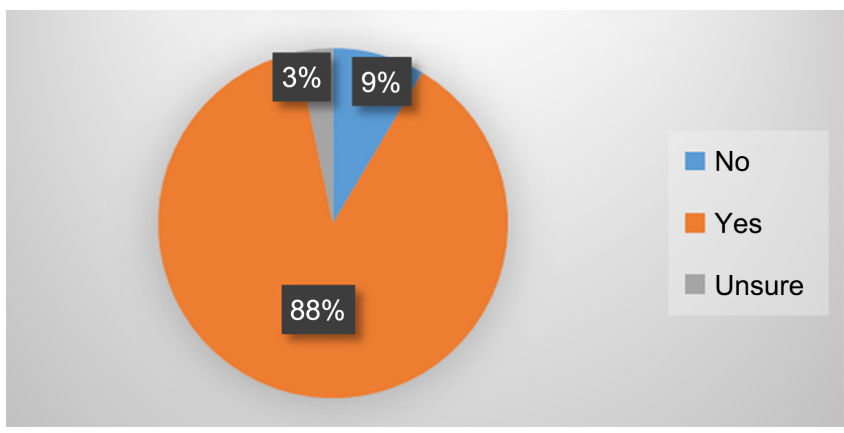

Figure 12. Percentage of population who undertands that they live on a wetland. Source: Field data 2019.

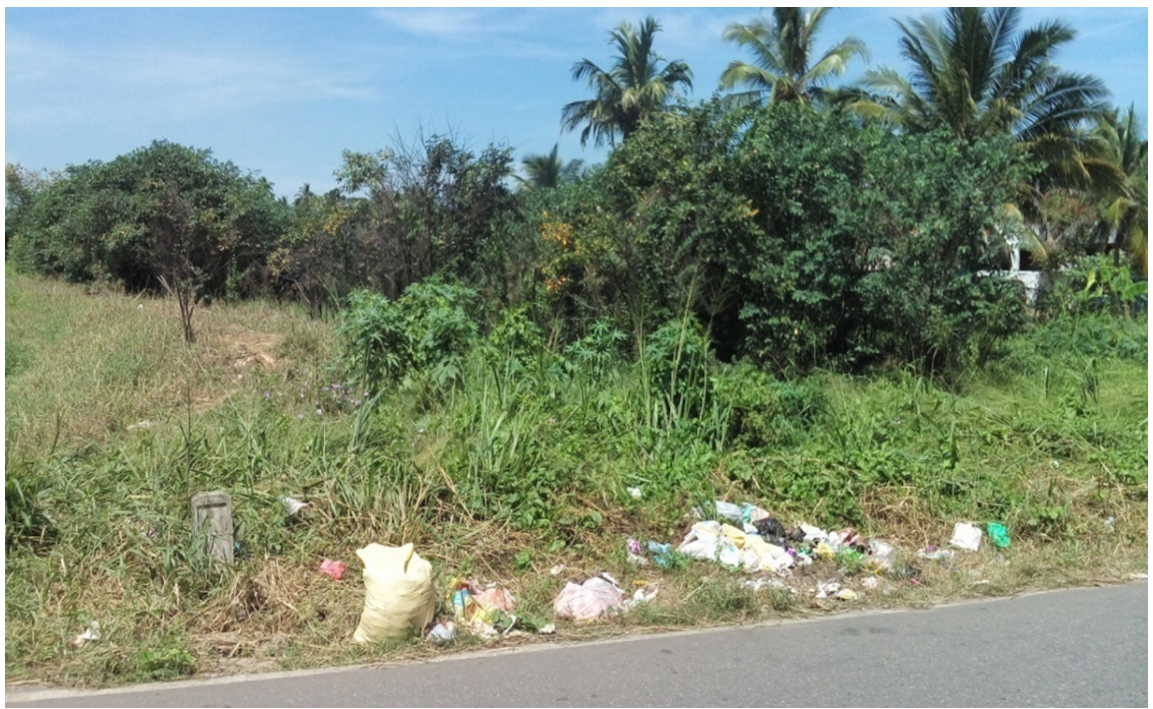

Figure 13. Waste dumping on the wetland in Catchment KO 17. 
The data confirm that the wetlands have been used as solid waste dumping sites by the settlers. According to the data collected, only $21.2 \%$ of people dispose their solid waste to municipalities or Pradesheeya Sabhas (Divisional Councils). And in the meanwhile, $10.2 \%$ directly dispose waste to the wetlands and the others which are $60.2 \%$ burn their solid waste on the wetlands. Our observations have proved that the settlers of the wetlands and nearby areas use these wetlands as dumping sites. Sometimes some of the industries and local governments also dispose their garbage directly into the wetlands. The data illustrates that $57.2 \%$ of the settlers identify these wetlands as garbage dumping sites. According to their general view, a wetland is a waste land. Therefore, the children and the youths have cleared the wetlands and use them as playgrounds during the dry seasons. According to the data, $\mathrm{KO} 08$ wetland is only used as a garbage dumping site. KO 12, 13, and 14 have been considered as garbage dumping site by $96.3 \%, 92.6 \%$, and $96.4 \%$ of settlers respectively. Meanwhile, no one has directly used KO 15 and 16 for any planned activities. These are real marshy lands and as shown in Figure 12, 88\% of the settlers who have already settled in the wetlands are aware that they live in the wetlands. The problem is that they damage to the sustainability of the wetlands. Even knowing the fact that they live in wetlands, they still cause damages to the sustainability of the wetlands.

The settlers of the catchment areas of Kalu Oya and Mudun Ela basins consider their living quality under 08 categories which are shown in Figure 14. According to the responses of the settlers, there are $39.2 \%$ families in lower middle-income level. Another $36.4 \%$ are in middle income level. The percentages of poor and very poor families are $12.9 \%$ and $1.9 \%$ respectively. The conclusion is that in majority of the catchment areas, numbers of poor or marginalized people are insignificant.

\subsection{Agriculture}

There are two types of agricultural activities on wetlands: Subsistence agriculture, and Commercial agriculture. Some of the resident families use their nearest wetlands for subsistence agriculture to fulfill their daily needs at small scale, less than an acre. Sometimes, there are large scale agricultural activities for earning money as a livelihood at commercial level. There are many subsistence agricultural activities on the wetlands; paddy cultivation, other crop cultivations like vegetables and tender natural wild leaves, livestock farming of animals like pigs, ducks, goats, grasses for animals, collecting soil and clay for domestic purposes, catching fish in natural water streams and the ponds of the wetlands (see Figures 15-17). The popularity and the abundance of these activities are varied by the catchments because these agricultural activities have adopted to the nature of the ecosystems in the wetlands. Generally, the vast areas of the wetlands had been converted to paddy cultivation in both the catchments but due to the dryness of the wetland and the marginal profits paddy cultivation has abandoned 


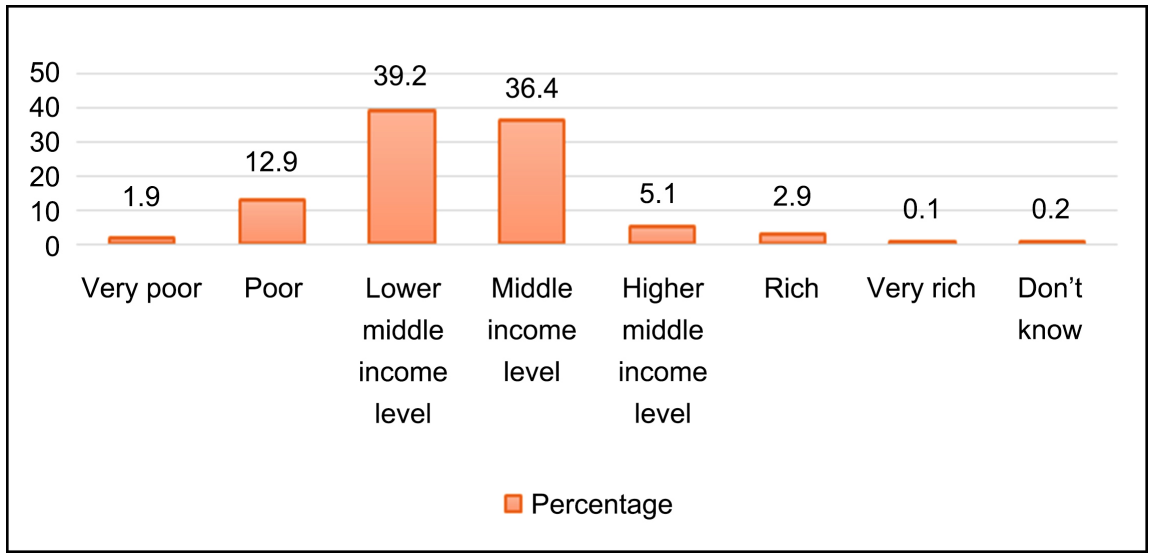

Figure 14. Living conditions of settlers defined by the settlers. Source: Field data 2019.

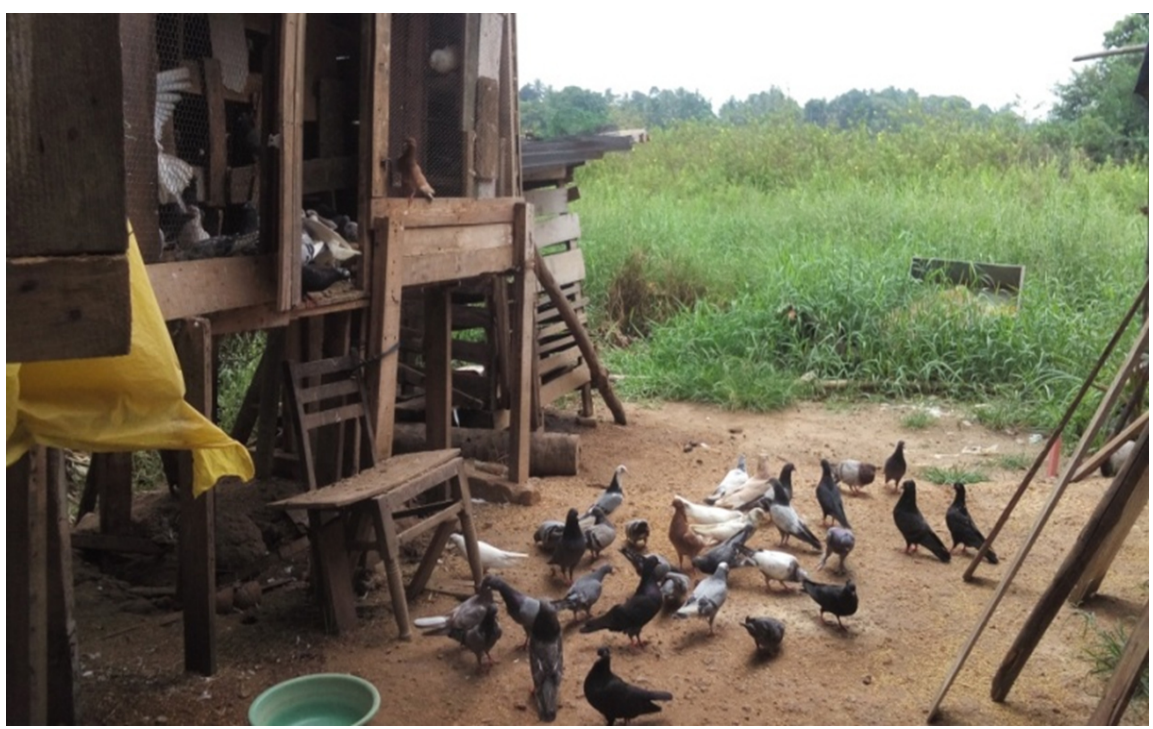

Figure 15. Bird farm near the wetland Horape, Catchment KO 09.

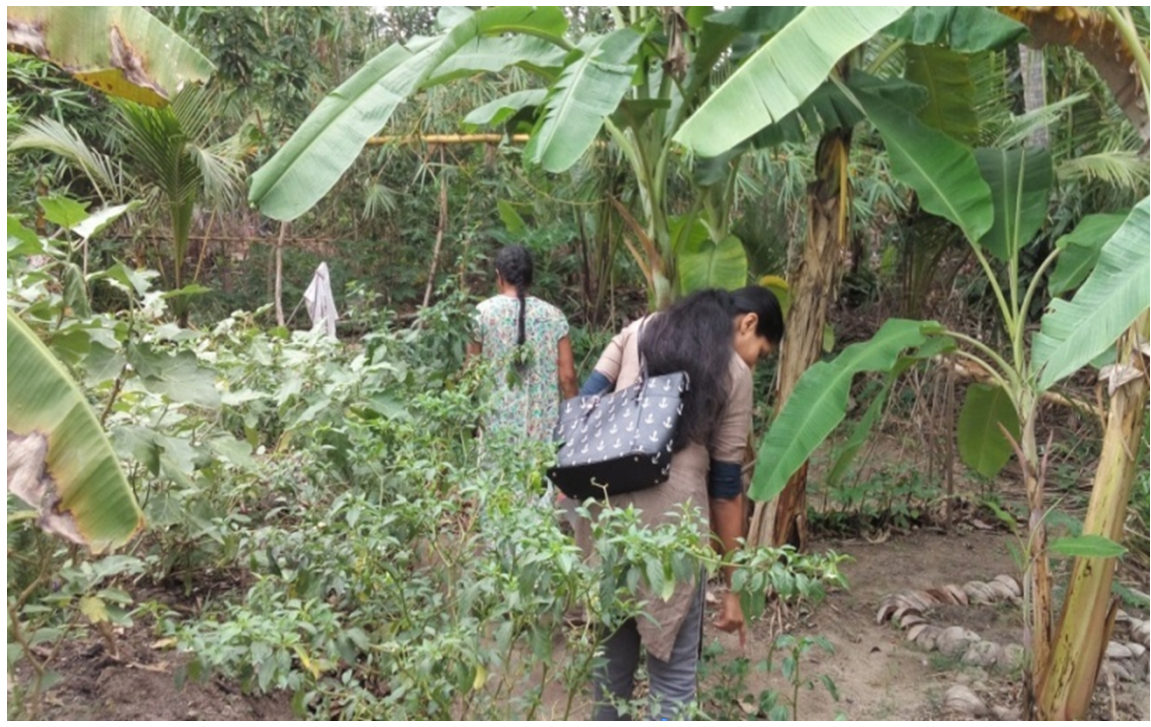

Figure 16. Koratu waga (enclosure cultivation on the wetland, Horape, Catchment KO 09. 


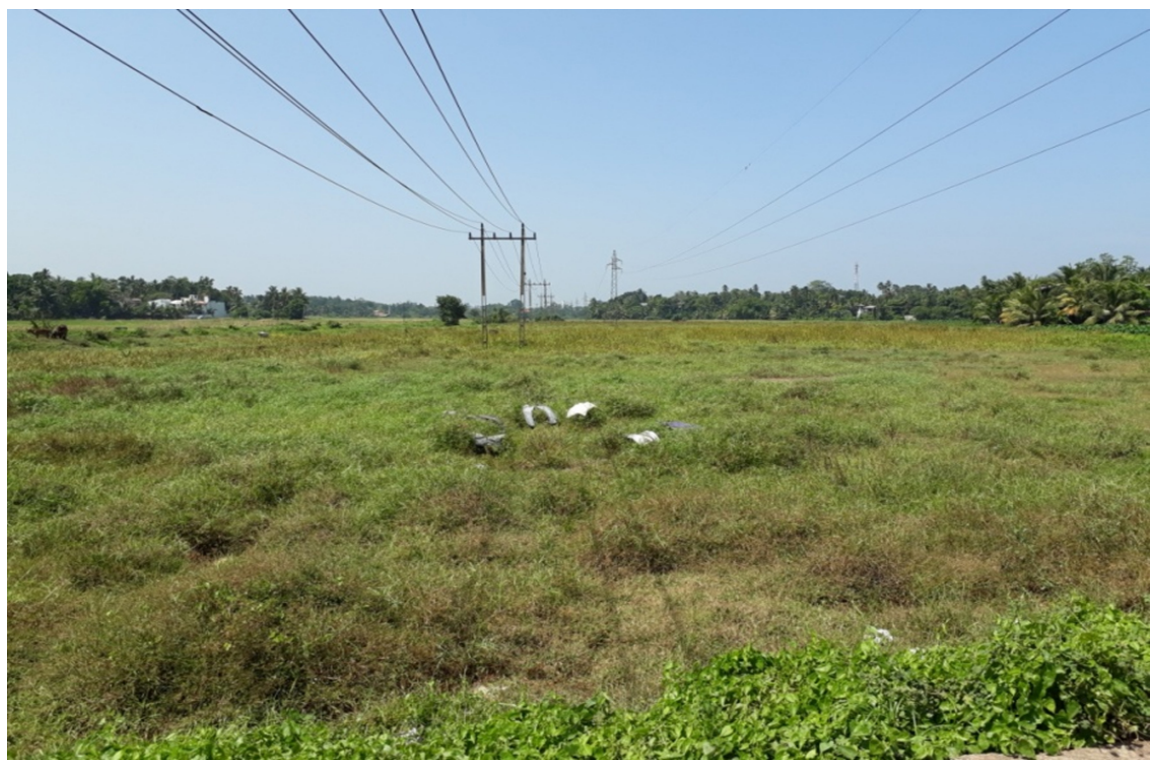

Figure 17. Abonedoned paddy fields in $\mathrm{KO} 07$.

since 1990s (Serasinghe, 2018). The best examples can be drawn from KO 07, $\left(7^{\circ} 0^{\prime} 7.48^{\prime \prime} \mathrm{N}\right.$ and $79^{\circ} 58^{\prime} 24.24 " \mathrm{E}$ to $6^{\circ} 58^{\prime} 26.05^{\prime \prime} \mathrm{N}$ and $\left.79^{\circ} 55^{\prime} 37.06^{\prime \prime} \mathrm{E}\right)$ which shows that about 20 acres of paddy lands have been abandoned. In our observations, the traditional farmer families do not like to cultivate paddy due to Rat Bite Fever (RBF) and aging of the traditional farmers. The current generations of the farmer families have been engaged in jobs related to non-agricultural sectors.

Almost 07 catchments out of 18 catchments; catchment 01, 05, 06, 10, 13, and 18, do not have commercial agricultural activities. The productions of these commercial activities are sold to the shops in the nearest city and they have a good marketing chain to sell their products. Majority of the owners of these lands are outsiders of the wetlands and the catchments. These land hunters have encroached these lands with the political support of the politicians (see Figure 18, Figure 19, \& Figure 20). Therefore, no one raises their voices against their illegal activities which have been done so far on the wetlands. Livestock farming: especially poultry farms and piggeries are the major activities in the wetlands and those activities are directly polluting the air, water, and the vegetation of the catchment areas. According to the settlers, these farms spread many germs and viruses and causes epidemics in the area. Even though they have complained to the police and other relevant authorities, there weren't any positive response because of political interference and bribery.

As explained above for several times in this article, the settlers have been generally thinking that the wetlands as waste lands. Therefore, people think that they can do anything on the wetlands without any hesitation. These wetlands are used for some of the seasonal cultural activities like providing free food for marginalized people in May and June months, new year festivals in April, alms giving for gods, Vesak lantern festival in May, and for sports like cricket, elle, football etc. during the dry season. 


\subsection{Political Interference}

Politicians interfere to damage the sustainability of wetland ecosystems. Some of the time they interfere directly and sometimes indirectly, some are visible while some are invisible. According to the people's evidences, major political intervention is for landfilling. In wetlands, local authorities implement some construction projects like jogging tracks, culverts, canals etc. and they use the wetlands as solid waste dumping sites. All the drainage systems which are maintained by the local authorities are directed to the wetlands. On the other hand, the local authorities have cleaned and widened the natural streams of the wetlands to mitigate floods. The central governments use wetlands for constructing highways on these catchments.

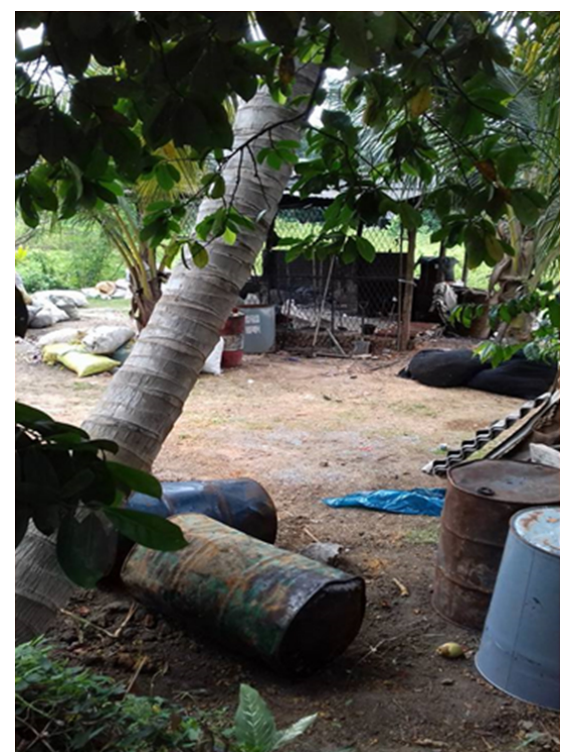

Figure 18. Aluminum burning site in Pamunuvila in Catchment KO 08 and industrial wastes.

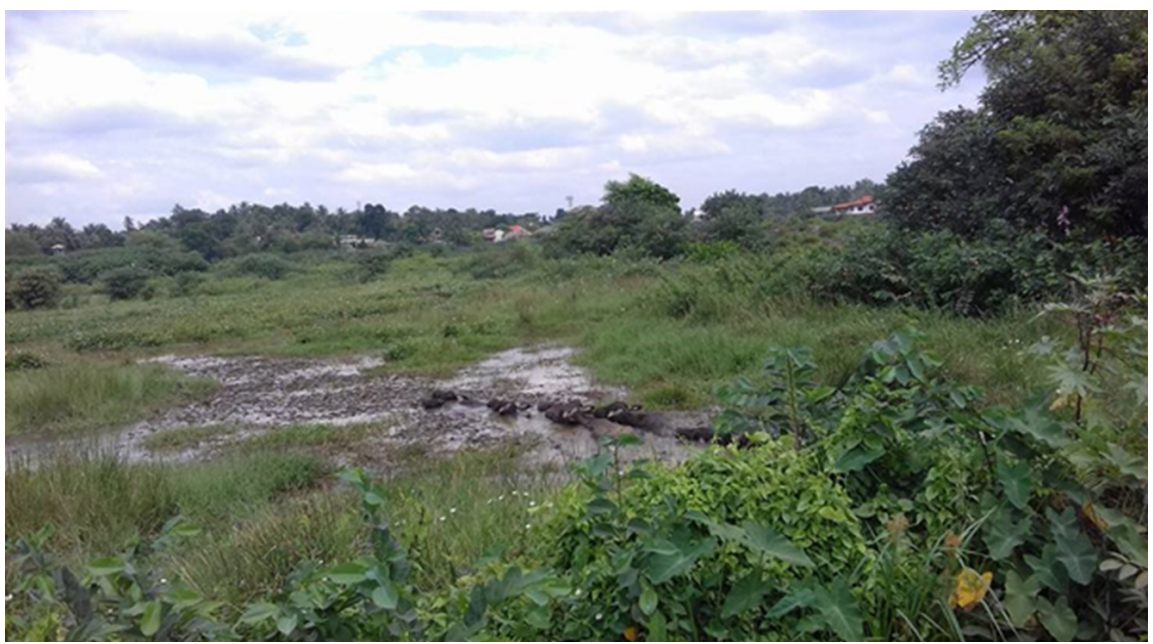

Figure 19. Waste deposits of Aluminum burning site in Pamunuvila in Catchment KO 08 and industrial wastes. 


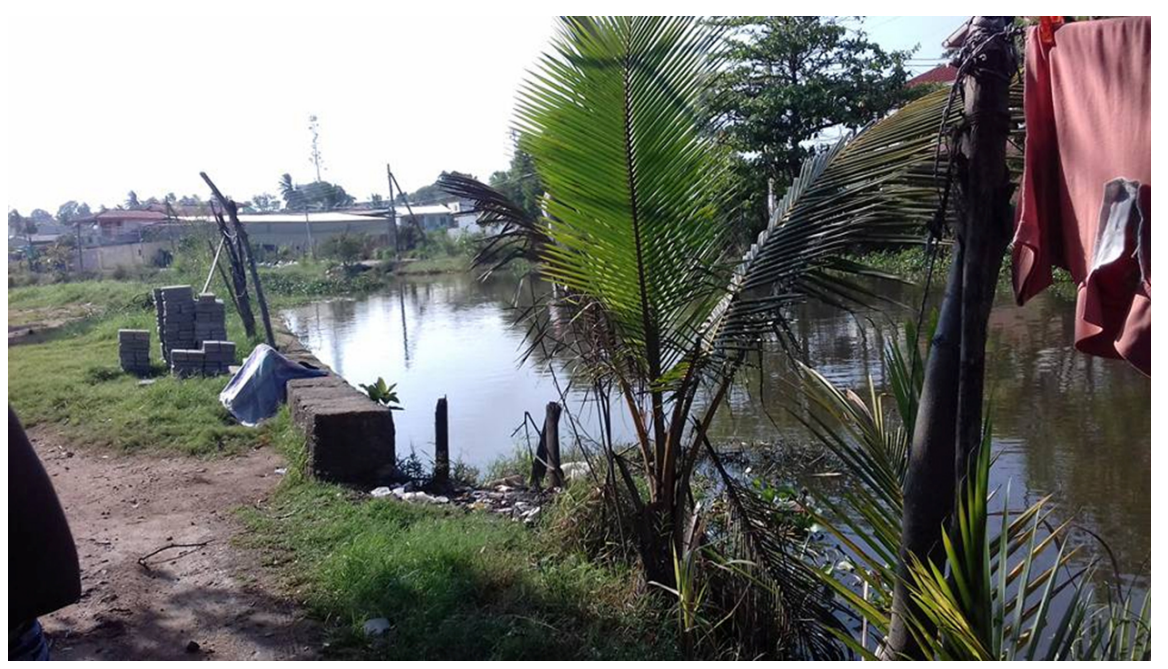

Figure 20. Unauthorized settlements and factories in Kalu Ela Wetland in Catchment KO 16.

According to the settlers' perceptions, major responsible party for protecting the wetlands is the government. Second and third responsible parties are village community and the large landowners of the wetlands. The settlers of the catchment areas suggest 05 types of wetland management strategies such as conservation, land filling, developing for human activities, reservation, and reclamation. These suggestions of the settlers are varied by the catchments. According to the data, majority is expecting to transform the wetlands for human purposes. The settlers fundamentally think that the wetlands are waste lands and those should be transformed to obtain direct benefits for human. The main reason behind the suggestions is lack of knowledge about the ecosystem services of the wetlands.

\section{Conclusion}

Historically, there were paddy fields, enclosure cultivation, fisheries and grass for domesticated animals in all the wetlands. Especially all the wetlands have one or more large paddy fields and the wetlands are commonly named as Wela, Welyaya or Kumbura (paddy field). Socio-economic backgrounds of the catchments are diversified, and majority of them are suburbs and urban peripheries. There are two types of settlers in the catchments within 300 meters; native settlers and migrated settlers in Mudun Ela and Kalu Oya basins. Migrants are the majority population in all the catchments, and they do not consider the wetlands to be important ecosystems. Some of them think that wetlands should be preserved as a nice scenery by clearing or landfilling for their wellbeing. Some of the outsiders of the catchments have been doing illegal activities on the wetland such as drug dealing, alcohol production (Kassippu), garbage dumping, desposing body parts of the killed animals, raping the women, child abuses etc. with the help of native population and politicians. Accordingly, the middle-class settlers want to stop these illegal activities for their security. Some of the native population seems to love the wetlands than the migrants. But generally native settlers identify the 
wetlands as waste lands.

Settlers and the landowners of the wetlands are not much acknowledged about the wetland ecosystems. More than 80 percent of the neighboring settlers of wetlands do not know the importance of the wetlands and their life support services to the human beings and the other services of these wetland ecosystems. The majority of the residents of the catchment areas are not poor or marginalized people but middle-class Sinhalese people. Economic activities of all the wetlands are approximately equal and the usage of wetlands is transforming from agricultural to industries and small services.

The livelihoods of the settlers in the catchments are not highly based on the wetlands. There is a significant percentage $(21.6 \%)$ who has built their houses within the wetlands. Percentage of the cultivated lands of the catchments is 0.47 . All the wetlands are threatened by solid and liquid waste dumping. Residents and the local authorities are responsible for this situation. Half of the lands of the settlement in the catchments belongs to highly flood risk areas which face flood at least twice a year mostly in the South-west monsoon period. Natural ecosystems have been rapidly changed during the last three decades, under the open market economic system. Urbanization and industrialization under the open economy have become the major reasons to encroach the wetlands.

Majority of the resident population who settled near the wetlands are middle class migrants from other parts of the country during the last three decades and they have bought the land from the land sales and directly from the natives. All the land sale owners have encroached the wetlands under the patronage of the politicians. This situation is common for all the wetlands. The invasive fauna and flora have been drastically increased during the last three decades of all the wetlands and it may be due to the reaction of land use changes during the same period. Especially, monitors and crocodiles come to the wetlands, seeking rotten meat and body parts of the killed animals which are on the dumping sites dumped by the meat shop owners and the large-scale farms, and dead animals on the garbage sites.

The scientific knowledge on the wetlands and their ecological services of the residents, landowners and also businessmen is significantly low. Majority of them think that these wetlands increase the risk of floods and vulnerability, except for highly educated people. All the residents are highly sensitive to the changes of the wetlands because they think that these wetlands as theirs. Therefore, any development in the wetlands should be implemented with participatory approaches. Except few places, there are no archeological sites in the catchment. But these few places are highly important due to their archeological and historical values.

All the catchments are influenced by politicians in numerous ways. Politicians are one of the major factors to change the wetlands because the politicians support to encroach the lands of wetlands to native populations, businessmen and land sales owners. According to the confirmation letters of the relevant institu- 
tions, there is no any projects or activities which are being implemented or to be implemented by the Central Environment Authority (CEA), The Department of Wild Life Conservation (DWLC), Agrarian Development Department (ADD), and Department of Railway.

Sri Lanka has just reached the level of lower middle-income country while significantly reducing the poverty headcount ratio. On the other hand, Sri Lanka is practicing various policies and strategies to achieve the sustainable development goals (SDGs). At the same time, the wetlands which are endemic to tropical environmental systems are endangered. Due to the rapid development of Colombo Megalopolis, the threats to the wetland in the Western Province of Sri Lanka have been increased. The Central Government, Provincial council of the Western Province and Local Governments in the wetland areas are highly responsible for protecting the life supporting services of the wetland for existing generation while ensuring the protection of wetlands for the future generations.

\section{Conflicts of Interest}

The author declares no conflicts of interest regarding the publication of this paper.

\section{References}

Census of Population and Housing Sri Lanka (2012). The Department of Census and Statistics, Colombo, Sri Lnaka. http://www.statistics.gov.lk/pophousat/cph2011/pages/activities/Reports/SriLanka.pdf

Google Earth Images (2014-2020). https://www.google.com/earth/

IUCN, Sri Lanka and the Central Environmental Authority (2006). National Wetland Directory of Sri Lanka, Colombo, Sri Lanka.

Kotagama, S. W., \& Bambaradeniya, C. N. B. (2005). An Overview of the Wetlands of Sri Lanka and Their Conservation Significance Department of Zoology. Univ. of Colombo in National Wetland Directory of Sri Lanka, Colombo, Sri Lanka, IUCN, Colombo. https://www.researchgate.net/publication/282702602 Status of Wetlands in Sri Lan ka

Land Use Map (1989). Surveying Department of Sri Lanka, Colombo, Sri Lanka.

Lekamge, M. L. D., Dayananda, M. D. N. R., \& Weerasinghe, V. P. A. (2018). Estimation of Crop Management Factor and Conservation Support Practice Factor of RUSLE Model to Assess Vulnerability to Soil Erosion in Kalu Oya and Mudun Ela Basins Using GIS. Research Symposium on Pure and Applied Sciences, 2018 Faculty of Science, University of Kelaniya, Sri Lanka, p. 133.

Piyadasa, R. U. K. A., Herath, H. M. M. S. D., Uthpalani, W. A. I., \& Sameera, D. (2018). GIS Based Spatial Analysis on the Soil Quality Variations of the Kalu Oya and Mudun Ela Basins Related to the Anthropogenic Wetland Alterations. In Conference Proceedings of Annual Research Symposium, 2018 Technology for Crossing Borders in Higher Education, of the Faculty of Technology, University of Colombo, Colombo, Sri Lanka.

Serasinghe, P. (2018). Willingness to Pay for Conservation of Wetland Ecosystem: Case of Mudun Ela and Kalu Oya Watersheds of Western Province of Sri Lanka. Nepal Journal of Environmental Science, 6, 39-45. https://doi.org/10.3126/njes.v6i0.30125

Thotagamuwa, H. T. B. N., \& Weerasinghe, V. P. A. (2019). Spatio-Temporal Variation of 
Surface Water Quality in Kalu Oya and Mudun Ela Micro-Catchments during Rainy Season (p. 28). 4th International Research Symposium on Pure and Applied Sciences, Faculty of Science, University of Kelaniya, Sri Lanka.

Daily News (2019).

http://www.dailynews.lk/2019/04/19/features/183295/conserving-wetlands-sri-lanka 